\title{
POSISI HUKUM TRADISIONAL DALAM \\ PERKEMBANGAN MENUJU HUKUM MODERN
}

Oleh:

\section{Anang Priyanto}

$\begin{aligned} & \text { Abstrak } \\ & \text { Pembicaraan hukum tradisional saat ini menjadi bahan }\end{aligned}$ kajian penting karena terkait dengan keberadaan hukum modern yang berkembang sesuai dengan perkembangan masyarakat Namun keberadaan hukum tradisional ini semakin terdesak dengan berkembangnya hukum modern yang dianggap lebih dapat memenuhi kebutuhan hubungan antar bangsa di dunia ketimbang hukum tradistional yang lebih bersifat kolektivitas kuat. Selama upaya pembentukan hukum nasional modern dilakukan, kekosongan hukum yang terjadi diisi dengan hukum kolonial yang masih berkembang yang tentunya kurang sesuai dengan perkembangan masyarakat saat ini. Pada situasi seperti ini hukum tradisional menjadi sangat penting dalam mengupayakan pembentukan konsep hukum modern guna menampilkan ciri atau identitas bangsa. Kesulitan timbul manakala hukum tradisional yang beraneka ragam jumlah dan jenisnya merupakan bahan kajian dan konsep materia dari pembentukan hukum modern yang lebih bersifat universal. Pelaksanaan hukum modern secara nasional sangat tergantung dari heierogenilas sosial alan politik, sirukiur elite, perkembangan birokratis dan kemungk̉inan penerimaan kebudayaan. Oleh̆ karena itulah tujuan pembentukan sistem hukum nasional yong modern harus mendasarkan pada kepentingan akan rasa persatuan dan kesatuan bangsa sebagia simbol nasionalitas, serta penghindaran adanya perasaan perbesaan kesukuan dan kedaerahan yang berpotensi sparatisme.

\section{A. PENDAhUluan}

Perkembangan hukum dewasa in yang di beberapa negara mengarah pada perkembangan hukum dalam kategori modern. Namun masih ada beberapa negara, terutama negara-negara yang sedang beerkembang, tata hukumnya disamping hukum modern juga masih ada hukum tradisioanl. Hukum modern dan hukum tradisional dalam negara berkembang merupakan wujud tata hukum yang bersifat pluralistik, artinya dalam realitas kehidupan

Majalah Informasi 
masyarakat hukum modern dan hukum tradisional berlaku secara berdampingan. Keadaan demikian juga dialami oleh negara Republik Indonesia melalui pasal II Aturan Peralihan Undang-Undang Dasar 1945 bahwa sistem hukum yang pluralistik pada jaman penjajahan Belanda tentunya masih untuk negara merdeka, terutama yang berkaitan dengan berlakunya hukum Eropa di satu sisi dan di sisi yang lain hukum yang bersesuaian dengan adat dan kebiasaan orang-orang Indonesia dan Timur Asing. Dualisme antara hukum Eropa dan hukum adat orang Indonesia ini telah banyak mendapat perhatian dari para ahli hukum Indonesia hingga saat ini.

$$
\text { Kemajuan teknologi }
$$

Oleh karena itulah keberadaan hukum adat menjadi permasalahan yang sering diperdebatkan oleh para ahli hukum dalam perkembangan hukum modern pada masa kini. Tidak hanya keberadaannya saja, tetapi bentuk dari hukum adat inipun telah banyak perbedaan pendapat dari para ahli hukum. Sebagian berpendapat, hukum adat sebaiknya dipakai untuk menyebut hukum yang tidak tertulis (non-statutair) sebagian lagi berpendapat bahwa hukum adat itu terdiri dari bagianbagian yang tertulis juga. Satjipto Raharjo (1986. 155) menggunakan istilah untuk penyebutan bentuk hukum adat ini dengan istilah hukum tradisional. Untuk itulah agar lebih informatika yang terjadi saat ini sangat jelas keberadaan hukum tradisional mempengaruhi perkembangan hukum ini, maka perlu dipecahkan modern yang mulai merambah pada permasalah-an bagaimana posis setiap negara di seluruh dunia yang hukum tradisional ini dalam tentunya mempengaruhi keberadaan perkembangan menuju hukum hukum setempat yang bernuansa nilainilai adat setempat, tak terkecuali di Indonesia.

Melalui politik hukum pemerintah di tingkat nasional, nampak kehadiran hukum adat menjadi kabur dalam realitas perannya pada kehiủujain masyarakat. Hal ini dikarenakan secara nasional hanya ada satu hukum yang berlaku secara nasional, yang pada saat ini masih sebagian besar mengambil alih produk hukum kolonial penjajah Belanda yang tentunya dengan berbagai penyesuaian menuju ke arah tuntutan perkembangan masyarakat modern. (sebagian terbesar) juga merupakan hukum yang tertulis meskipun hanya sebagian terkecil, seperti misalnya dapa diketemukan dalam bermacam-macam piagam raja (=surat pengesahan raja atau kepala rakyat) dan kitab-kitab hukum yang ditentukan oleh kerajaan, misalnya Kasunanan, Mangkunegaran Pakualaman dahulu "Angger-arubiru" (1782), "Nawolo Pradoto" (1771,1818), "Peraturan Bekel" (1884); di daerah Batak "Ruhut Pasaoron d Hobatahon" dan "Patik Dohot Uhum ni Halak Batak"; dan lain-lain. (Utrecht.1953.56-57).

Hukum adat atau disebut juga hukum tradisional telah berukat-berakar pada kebudayaan tradisional. Hal ini diperkuat dengan apa yang dikemukakan oleh Soepomo (1996: 3; 20) sebagai seorang ahli hukum adat yang menyatakan bahwa hukum adat adalah suatu hukum yang hidup, karena ia menjelmakan perasaan hukum yang nyata dari rakyat. Sesuai dengan firtahnya sendiri, hukum adat terus menerus dalam keadaan tumbuh dan berkembang seperti hidup itu sendiri. Hukum adat yang tradisional menunjukkan adanya nilai-nilai universai seperti asas gotong-royong, fungsi sosial manusia, dan milik dalam masyarakat, asas persetujuan sebagai dasar kekuasaan umum, asas perwakilan dan permusyawaratan dalam sistem pemerinntahan.

Dalam perkembangannya karena pengaruh kontak dengan masyarakat lain tidak selamanya hukum tradisionąl. hanya terdiri atas anasir-anasir asli yang terdapat didalam kebudayaan Indonesia sebelum pengaruh Hindu dan Islam, melainkan juga ada anasir-anasir hukum Barat yang lama kelamaan diterima sebagai hukum adat. Hukum tradisional sangat diyakini oleh masyarakat adat sebagai hukum yang harus ditaati tanpa kecuali, tentunya dengan sanksi yang berat bagi yang melanggarnya. Bagi masyarakat adat yang masih memegang teguh adat istiadat setempat, maka penerapan hukum adat bagi warganya sangat mutlak dilakukan, sehingga sanksi yang dijatuhkan terhadap' pelanggar hukum adat (tradisional) amatlah tegas yang kadang-kadang apabila dikaitkan dengan kepentingan nasional sanksi itu dianggap kurang "manusiawi".

$$
\text { Melalui politik hukum }
$$

nasional terhadap sanksi adat yang dijatuhkan sangatlah tergantung pada hakim yang mengadilinya yang juga mempunyai fungsi mengädakan upaya transformasi masyarakat melalui hukum, seperti misalnya apa yang tercantum dalam Pasal 27 ayat (i) Ūndang-undang Nomor 3s Tahun 1999 (Undang-undang tentang Perubahan Atas Undangundang Nomor 14 Tahun 1970 tentang Ketentuan-ketentuan Pokok Kekuasaan Kehakiman) yang menyatakan: "Hakim sebagai penegak hukum dan keadilan wajib menggali, mengikuti dan memahami 
nilai-nilai hukum yang hidup dalam masyarakat". Dengan tegas Soepomo (Soerjono Soekanto. 1986. 53) mengatakan bahwa fungsi seorang hakim adalah berwenang dan bahkan wajib untuk menelaah apakah suatu peraturan hukum adat yang telah ada mengenai soal yang dihadapi masih selaras atau tidak dengan kenyataan sosial sehubungan dengan perubahanperubahan yang terjadi di dalam masyarakat. Hakim tidak boleh mengadili semata-mata menurut perasaan keadilan peibadi, tetapi dia terikat pada nilai-nilai yang secara nyata berlaku dalam masyarakat. Dengan keputisan-keputusan diharapkan seorang' hakim memperkuat kehidupan norma hukum yang bersangkutan.

Meskipun hukum tradisional ini sebagian besar bersifat tidak tertulis, namun keberadaan hukum ini diakui dalam masyarakat sebagai hukum yang mengikat dengan sanksi moral yang berat dan selalu ditaati oleh setiap anggota masyarakat dengan tulus, sehingga tanpa pengawasan yang ketat dari penguasa adatpun hukum tradisional ini efektif berlaku dalam kehidupan masyarakat.

\section{DIRI-DHR \\ rYUKUN \\ TRADISIONAL DAN HUKUM} MODERN

Ciri-ciri yang dikemukakan dalam hal ini menunjuk pada perbedaan antaraa hukum tradisional dengan hukum modern agar keberadaan kedua bentuk hukum tersebut menjadi jelas dalam kehidupan masyaarakat. Adapun ciri-ciri hukum tradisional (Ronny Hanitijo Soemitro. 1984. 54) dapa dikemukakan sebagai berikut:

1) Hukum tradisional mempunyai sifat kolektivitas yang kuat.

2) Mempunyai corak magisreligius yaitu yang berhubungan dengan pandangan hidup masyarakat asli.

3) Sistem hukumnya diliputi oleh pikiran yang serba konkrit, artinya hukum tradisional sangat memperhatikan banyaknya dan berulang ulangnya hubungan-hubungan yang konkrit yang terjadi di dalam masyarakat.

4) Sistem hukum tradisional bersifat visual, artinya hubungan-hubungan hukum dianggap terjadi hanya karena ditetapkan dengan suatu ikatan yang dapat dilihat atau dengan suatu tanda yang tampak.

Menurut Soepomo seperti yang dikutip oleh Soejono Soekanto (1986. 181-182), bahwa cir kolektivitas yarig kuat dari hukum tradisional merupakan corak yang khas dari suatu masyarakat yang hudup terpencil ataù mâsyarakakat yang didalam kehidupan sehari-har masih sangat tergantung pada tanah atau alam pada umumnya. Kepentingan-kepentingan individual agak terdesak ke belakang, dan masyarakatlah yang senantiasa memegang peranan yang menentukan, yang pertimbangan dan patokannya

tidak

boleh kepentingan-kepentingan individu selalu diimbangi dengan kepentingankepentingan umum, dan segala penilaian, keputusan dan tekanan terletak dalam tangan rakyat. Sedangkan pengertian magis-religius pada hakekatnya merupakan suatu pembulatan atau perpaduan kata yang mengandung unsur-unsur berfikir animisme, pantangan-pantangan, ilmu gaib dan sebagain. Untuk cara berfikir yang selalu menncoba dan menusahakan agar hal-hal yang dimaksud, diingini, dikehendaki ataupun yang akan dikerjakan diberi wujud suatu benda, sekalipun fungsinya hanya sebagai lambang saja. Sifat konstan atau tunai yang terdapat dalam hukum tradisional pada umumnya merupakan suatu pengertian bahwwa dengan suatu perbuatan nyata, suatu perbuatan simbolis atau suatu ucapan, maka tindakan hukum termaksud telah selesai seketika itu juga. Dengan demikian, segala sesuatu yang terjadi sebelum dan sesudah tindakan hukum tersebut adalah di luar tindakan tersebut, artinya tidak ada sangkut pautnya dan tidak mempunyai huibuingan sebab dañ akibat. Pendukung dari hukum tradisional ini biasanya mereka adalah masyarakat yang tertutup sifatnya, artinya masyarakat deñgan hukum dan lembaga-lembaga tradisionalnya merupakan faktor-faktor yang sangat menentukan dalam proses sosialisasi yang tidak dapat ditinggalkan oleh para warga masyarakatnya. (Satjiipto Rahardjo. 1986. 155). Kehidupan yang demikian itu masih diketemukan dalam kehidupan sebagian masyarakat Indonesia. Oleh karenanya apabila masyarakat tertutup demikian tetap dipertahankan, maka masyarakat itu harus menciptakan mekanisme sendiri, agar keberadaan hukum tradisional tidak tersisih dengan adanya sistem negara yang modern saat ini.

Seperti yang telah terjadi di negara-negara berkembang, bahwa kenyataannya apabila masih ada dua atau lebih sistem hukum yang berlaku secara berdampingan, maka kecenderungan pilihannya ada pada sistem hukum yang modern. Sistem hukum modern tentunya mempunyai ciri yang jauh berbeda dengan hukum tradisional, untuk itulah ciriciri hukum modern periu diungkap agar lebih jelas perbedaan yang ada. Secara terperinci Marc Galanter (Ronny Hanitijo Soemitro. 1984 54-56) mengajukan ciri-ciri hukum modern ini sebagai berikut:

1. Hukum modern terdiri dari peraturan peraturan uniform dan konsisten dalam penerapannya. Penerapannya lebih bersifat teritorial daripada personal, yaitu tidak membedakan agama, suku bangsa, kasta, jenis kelamin.

2. Hukum modern bersifat transaksional, maksudnya hak- 
hak dan kewajiban-kewajiban tumbuh dari transaksi-transaksi, yaitu antara lain umpananya kontrak-kontrak, pelanggaranpelanggaran perdata dan pidana. Dalam hukum modern hak-hak dan kewajiban-kewajiban tidak timbul sebagai akibat dari keanggotaan seseorang dalam suatu lingkungan tertentu.

3. Hukum modern bersifat universal Pengaturan mengenai hak-hak yang khususpun juga tiidak terlepas dari ukuran-ukuran yang bersifat umum. Cara-cara pengaturan secara intuisif dan bersifat unik tidak terdapat di dalam hukum modern. Penerapan hukum dapat dijalankan berulangulang dan dapat diduga sebelumnya mengenai apa yang akan terjadi (predictable).

4. Sistem hukum modern bersifat hierarkhis (berjenjang). Terdapat jaringan penerapan hukum yang teratur, mulai dari tingkat pertama meningkat ke banding dan seterusnya. Dengan demikian maka keputusan-keputusan setempat lalu dapat disesuaikan dengan standarstandar nasional, dan juga

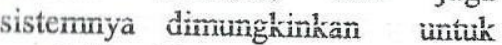
menjadi uniform serta dapat diduga sebelumnya

5. Sistem hukum modern diorganisasi secara birokratis. Untuk dapat mencapai uniformitas, sistem hukum modern harus bekerja secara impersonal, mematuhi prosedurprosedur yang ditentukan untuk setiap kasus dan memberikan keputusan untuk setiap kasus itu sesuai dengan ketentuan yang tertulis.

6. Sistem hukum modern bersifat rasional. Peraturan-peraturan dinilai dari segi kemanfaatannya secara instrumental, yaitu apakah peraturaan itu mampu dipakai untuk memperoleh hasil. yang dikehendaki. Hukum dengan demikian tidak dinilai dari kualitas formalnya, tetapi dinilai dari kualitas fungsionalnya.

7. Sistem hukum dijalankan oleh ahli-ahli yang khususnya belajar untuk menjalankan fungsi itu. (professionals).

8. Sistem hukum modern dapat diubah-ubah dan tidak dianggap suci. Sistem yang modern memuat metode-metode dan cara-cara untuk melakukan peninjauan kembali peraturan-. peraturan dan prosedurprosedur untuk menghadap kebutuhan-kebutuhan yang berubah atau perubahanperubahan dalam prioritaspriơitâs.

9. Sistem hukum modern bersifat politis. Hukum dikaitkan dengan negara, negara mempunyai monopoli dalam membuat peraturan-peratuarn hukum. Badan-badan lain yang juga menjalankan fungsi seperti itu harus memperoleh persetujuan negara.

10. Tugas untuk menemukan dan menerapkan hukum dipisahkan dan dibedakan, baik mengenai personalianya maupun tekniknya dari tugas-tugas lain yang dijalankan oleh pemerintah, sehingga dipisahkan serta dibedakan tugas-tugas legislatif, yudiktif, dan eksekutif.

Dari ciri-ciri diatas secara garis besar dapatlah diambil kesimpulan bahwa hukum modern itu mempunyai bentuk tertulis; berlaku untuk seluruh wilayah negara; terdiri dari peraturanperaturan yang bersifat uniform dengan diterapkan tanpa mengenal variasi, dan peraturan-peraturan tesebut lebih bersifat teritorial dari pada pribadi, artinya peraturan yang sana diterapkan terhadap anggota-anggota masyarakat dari semua suku, agama, kelas, daerah dan kelamin.: Hukum modern merupakan instrumen yang dipakai secara sadar untuk mewujudkan keputusan-keputusan politik masyarakatnya. (Satjipto Rahardjo. 1996. 214).

Meskipun apabila ada dua sistem hukum yang berbeda dalam sumber nilai-nilainya dan sistemnya berlaku bersamaan dalam kehidupan masyarakat dalam wilayah negara yang sama memang akan dapat pula menimbuiakn persoalan, maka tentunya harus dilakukan tindakan pemecahan persoalan tersebut dan hal ini pernah. juga dilakukan, misalnya dengan alternatif pemecahan pengaturannya seperti yang terjadi pada masa penjajahan Belanda di Indonesia dahulu, yaitu dengan membagi-bagi penduduk Indonesia ke dalam beberapa golongan penduduk dengan masing-masing golongan ditentukan hukum yang berlaku bagi mereka, misalnya untuk orang Indonesia asli berlaku hukum adatnya masing-masing, sedangkan untuk orang Eropa berlaku hukum Eropa. Namun dalam suasana Indonesia merdeka sekarang ini, yang menjadikan perubahan kondisi masyarakat dari terjajah menjadi masyarakat bebas, menyebabkan juga politik hukum yang dijalankan tentunya' mengalami perubahan, bahwa penyusunan sistem hukum yang baru diarahkan kepada satu sistem hukum nasional yang menuju ke arah perkembangan masyarakat modern. Hal ini menjadikan berbagai pertanyaan terhadap posisi hukum adat atau hukum tradisionai pada masa kini

\section{KEDUDUKAN HUKUM TRADISIONAL PIRKEMBANGAN MENUJU MODERN \\ Seperti telah disinggung} daiam pembahasan di atas, bahwa persoalan timbul jika dua sistem hukum secara bersamaan berlaku dalam kehidupan masyarakat pada wilayah negara yang sama. 
Sebenarnya pada masa penjajahan kebutuhan hubungan antar bangsaBelanda di Indonesia dahulu; bangsa di dunia menuju ke arah pemerintah kolonial Belanda saat itu lebih menghargai hukum adat dengan memasukkannya dalam tata hukum melalui struktur hukum, pendidikan dan ideologi dibanding dingan kolonikoloni Eropa lainnya, serta lebih bersifat untuk kepentingan Belanda daripada kepentingan masyarakat Indonesia dahulu. Setelah merdeka, pemerintah pada saat itu telah mengambil sikap yang progresif tentang hukum dan peranannya dalam masyarakat agar tidak terjadi kekosongan hukum, untuk itulah paling sedikit ada beberapa alasan yang "amat mendesak untuk segera diambil; yakni:

1) Keinginan untuk secepatnya menghapuskan peninggalan kolonial;

2) Harapan-harapan yang ditimbulkan pada masyarakat dengan tercapainya kemerdekaan; dan,

3) Tuntutan uniuk survive sebagai anggota masyatakat dunia. (Sunaryati Hartono. 1991.82)

Pada masa sekarang walaupun hukum adat merupakan milik bangsa Indonesia, namun dengan politik dan administrasi pemerintah pada tingkat nasional seolah-olah menjadi kabur keberadaannya karena munculnya konsep hukum nasional sebagai penekanan pada identitas negara hukum tertulis. Lebih-lebih menghadapi masa globalisasi saat ini, hukum modern lebih dominan mewarnai kehidupan masyarakat guna mengantisipasi

\section{perkembangan dunia modern.}

Hukum modern lebih bisa nenenuhi kebutuhan masyaraka modern ketimbang hukum tradisional yang lebih bersifa kolektifitas kuat. Oleh karenanya pembentukan hukum nasional yang mampu melayani nilai-nilai dan kebutuhan-kubutuhan masyarakat Indonesia Baru dengan majunya teknologi dan informasi, yang paling tepat dilakukan adalah dengan pembentukan hukum yang dikategorikan modern dengan penyesuaian-penyesuaian dan pengambilalihan berbagai peraturan negara-negara maju. Namun dalam hal pengoperan hukum bangsa lain hal ini menurut Siedman sepert yang dikutip oleh Satjipto Rahardjo (1986. 166) tidak dapat dilakukan dan ini didasarkan pada analisa sebagai berikut: terhadap pertanyaan mengenai bagaimana seorang pemegang $d i$ dalam masyarakat itu akan bertindak, maka kita harus melihatnya di dalam hubungan dengan fungsi dari faktor-faktor yang berbubungan dengan peranan yang diharapkan dari seseoarng itu. Dan fungsifungsi tersebut adalah:

a. peraturan-peraaturan yang ditujukan kepadanya;
1. Untuk memberikan jawaban b. sanksi-sanksi tersebut;

c. aktivitas-aktivitas lembagalembaga penerap, seperti polisi, jaksa dan sebagainya;

d. keseluruhan komplek sosial, politik, ekonomi dan lain-lain kekuatan mempengaruhinya

2. Apabila kita melihat bahwa peraturan-peraturan tertentu telah berhasil untuk menggerakkan aktivitas seseorang, maka hal itu adalah sesuatu yang bersifat khas untuk setiap keadaan tertentu

3. Penggunaan norma-norma hukum yang sama berikut sanksi-sanksinya itu harus kita tempatkan di dalam konteks waktu-waktu, serta tempattempat tertentu. Oleh karena itu, maka penggunaannya untuk waktuwaktu dan tempat-tempat yang berlainan, dan disamping itu juga dengan lembaga-lembaga penerap sanksi yang beriainan serta kompleks sosial, politik, ekonomi dan kekuatañ-kekuatañ lain yang mempengaruhi seorang pemegang peranan yang berlainan pula, tak dapat diharapkan akan menimbulkan aktivitas pada pemegang peranan tersebut yang sama dengan yang terjadi pada asal norma-norma tersebut.

Dalam posisi yang demikian (seperti tersebut diatas), hukum tradisional semakin terdesak keberadaannya dan hanyakah merupakan ceritera sejarah, namun sebenarnya secara hakiki yang masih tersisa di dalam kehidupan masyarakat sebagai kebiasaan yang jauh berbeda dengan hukum modern (hukum). Kebiasaan atau ada bersifat otonom dan spontan, sedang hukum merupakan suatu produk dari kekuasaan yang terorganisasi yang disebut "Negara". Kebiasaan tidak diberi sanksi oleh suatu kekuasaan politik yang terorganisir, sebaliknya sanksi sangat penting bagi pelaksanaan hukum. (Sunaryati Hartono. 1991. 12). Sebagai kebiasaan yang hidup di masyarakat dihadapkan pada hukum modern yang berkembang, menyebabkan posisinya menjadi seolah-olah tak berkekuatan sama sekali dan hanyalah berharap dukungan mora warga masyarakat guna melegitimir keberadaannya.

Untuk menuju pada pembentukan sistem hukum nasional, berbagai upaya telả dilakukan dan berbagai konsep tclah terbentuk, namun kemauan politik kurang mendukung meskipun upaya pembentukan hukum modern tidak meninggalkan hukum modern tidak meninggalkan nilai-nilai tradisional masyarakat. Selama upaya pembentukan hukum nasional yang modern dilakukan, kekosomgan hukum diisi dengan hukum kolonial yang masih berkembang yang tentunya kurang sesuai dengan perkembangan masyarakat saat ini. Pada situasi 
seperti ini hukum tradisional menjadi sangat penting dalam mengupayakan pembentukan konsep hukum modern guna menampilkan ciri atau identitas bangsa. Kesulitan timbul manakala hukum tradisional yang beraneka ragam jumlah dan jenisnya merupakan bahan kajian dan konsep material dari pembentukan hukum modern yang lebih bersifat universal. Untuk itulah pelaksanaan yang bersifat nasional dari hukum modern sangat tergantung dari heterogenitas sosial dan politik, struktur elite, perkembangan birokratis dan kemungkingan penerimaan kebudayaan. Kepentingan akan rasa persatuan dan kesatuan bangsa sebagai simbol nasionalitas, serta penghindaran adanya perasaan perbedaan kesukuan dan kedaerahan yang mungkin berpotensi sparatisme lebih menjadi tujuan utama pembentukan sistem hukum nasional yang modern.

Dalam pembentukan sistem hukum modern yang bersifat nasional, bahan kajian material hukum tradisional dari berbagai suku bangsa yang ada sangatlah mendukung eksistensialitasnya dalam kehidupan masyarakat. Peters dan Koesriani Siswosoebroto (1988, 177) חicriyatakañ baakwa modernisasi hukum nasional tampaknya mencakup arus umum tertentu, yakni

1. penerapan hukum kepada daerah ruang, etnis dan kelas yang lebih luas;

2. penggantian hukum perorangan oleh hukum teritorial:

runtuhnya pertanggungjawaban bersama oleh pertumbuhan hak individual;

4. meningkatkan pikiran umum dan keniskalaan; pengkhususan dan profesionalisme yang membesar, begitu juga sekularisasi, birokratisasi, penggantian intuisi mora dengan keahlian tehnik.

$$
\text { Dalam }
$$
memandang

pembentukan hukum modern dan peranannya dalam masyarakat di berbagai negara sangatlah tergantung pada konservatif tidaknya pihak penguasa. Demikian seperti yang dikemukakan oleh Sunaryati Hartono (1991. 82) bahwa negaranegara otokrasi yang dikuasai oleh golongan yang eksklusif akan cenderung menolak perubahan, dan karenanya cenderung pada pemikiran konservatif tentang bukum, sehingga hanya melihat hukum sebagai alat untuk menjaga keamanan dan ketertiban.

Penguasa yang lebih melihat perkembangan hukum terkait dengan perkembangan masyarakat akan veruampak pada perubahan hukium yang ada sebagai tuntutan pemenuhan ketentraman kehidupan bersama. Oleh karena itulah pemikiran menggantikan hukum konservatif warisan pemerintah kolonial dengan suatu pemikiran hukum yang lebih memperhatikan kebutuhan masyarakat yang sedang membangun ke arah modernitas dianggap sesuatu yang wajar.

Pembentukan pembaháruan

hukum bagi masyarakat modern lebih bersifat tertulis, sehingga perundangunndangan merupakan suatu cara untuk melakukan pembaharuan hukum tersebut. Namun kenyataannya ada pendapat dari suatu aliran sejarah (madzab sejarah), bahwa hukum itu tidak dibuat melainkan harus tumbuh sendiri dari kesadaran hukum masyarakat. Aliran sejarah ini ingin mempertahankan keberadaan hukum tradisional sebagai pencerninan dari nilai-nilai budaya asli penduduk pribumi dan mencegah terjadinya modernisasi ke arah westernisasi. Oleh karena itulah hukum tradisional sampai saat ini dipelihara dan tersimpan sebagai modal dasar bangsa menunjuk pada identitas bangsa dalam kehidupan masyarakat dunia. Sebagai modal dasar, hukum modern yang dibentuk haruslah mendasarkan pada hukum tradisional sebagai faktor matrial agar nilai-nilai tradisional masyarakat benarbenar tercover, sehingga identitas bangsa mewarnai ini hukum modern. Permasalahannya akan timbul mampukah hükuin môdeñ menampinin nilai-nilai tradisional bangsa Indonesia yang 300 ctnis lebih jumlahnya?

Munculnya gerakan reformasinasional yang berhasil menggulingkan rezim Orde Baru posisi hukun tradisional mulai dipermasalahkan dalam kedudukan hukum nasional, bahkan mendapat sambutan yang berlebihan dari masyarakat adat yang pada kenyataannya dapat membahayakan munculnya disintegrasi bangsa. Lebih disayangkan lagi posisi hukum tradisional dalam lingkup pembangunan hukum masional justru dipersepsikan sebagai kekuatan adat kedaerahan yang dapat menyebabkan munculnya disintegrasi. Ditambah lagi sikap arogan dan kebijaksanaan politik penguasa yang lebih mementingkan kepentingan kelompok untuk tujuantujuan politik sesaat serta mengesampingkan rasa penderitaan bersama seluruh rakyat yang ada di setiap daerah dalam menghadapi krisis ekonomi dan kurangnya perhatian membahayakan kepentingan hukum nasional modern.

\section{E. PENUTUP}

Hukum modern berkembang sesuai dengan perkembangan masyarakat saat ini karena pengaruh kemajuan teknologi dan informatika yang telah mewarnai konsep hukum pada semua negara di dunia. Munculnya hukum modern sangat mempengaruhi keberadaan hukum tradisional, dikarenakan keduanya mempunyai ciri-ciri yang berbeda, namun pada negara-negara berkembang termasuk Indonesia hukum tradisional masih diakui keberadaannya dalam masyarakat disamping hukuim modern. Hukum 
tradisional yang merupakan hukum yang berurat-berakar pada kebudayaan nasional serta merupakan hukum yang hidup dan penjelmaan perasaan hukum rakyat perlu dipertahankan keberadaannya. Meskipun apabila dua sistem hukum tersebut berjalan bersama dan diakui keberadaannya, namun pilihan yang utama ada pada hukum modern guna penyesuaian kondisi jaman pada masa kini. Oleh karena itulah pemberitukan hukum modern tetap menggunakan faktor materiil hukum tradisional sebagai modal dasar agar nilai-nilai tradisional dan identitan bangsa tetap terjaga dalam pergaulan bangsa-bangsa di dunia Politik hukum penguasa dalam hai ini sangatlah menentukan eksistensi hukum trasisional dalam realitas kehidupan masyarakat menuju ke arah perkembangan modernitas.

\section{DAFTAR PUSTAKA}

Peters dan Koesriani Siswosoebroto. (1988) - Kon Perkembangan Sosial Buku Teks Sosiologi Hukum Buku II. Pustaka Sinar Harapan. Jakarta.

Ronny Hanitije Soemitro. (1984). Masalah-masalah Sosiologi Hukum. Sinar Baru. Bandung

Satjipto Raharjo. (1986). Hukum dan Masyarakat. Angkasa. Bandung. . (1996). Ilmu Hukum.

PT Citra Aditya Bakti. Bandung.
Soepomo. (1996). Bab-bab Tentang Hukum Adat. PT. Pradnya Paramita. Jakarta.

Soerjono Soekanto. (1986). Pokokpokok Sosiologi Hukum. Rajawali Pers. Jakarta

Sunaryati Hartono. (1991). Politik Hukum Menuiu Suat Sistem Hukum Nasional. Alumni. Bandung.

Utrecht. (1953). Penantar Dalam Hukum Indonesia. NV. Penerbian dan Balai Buku Indonesia. Jakarta.

\section{PENILAIAN KUALITAS PERMUKIMAN KOTA BERDASARKAN FOTO UDARA DAN SISTEM INFORMASI GEOGRAFIS \\ OIeh \\ Bambang Syaeful Hadi*)}

\section{ABSTRAK}

Permukiman kota sebagai bagian dan penggunaan lahan kota tumbuh secara cepat akibat bertambahnya penduduk dan makin beragamnya aktivitas penduduk. Untuk itu para pengelola dan perencana kota perlu mengantisipasi dan memantau kualitas permukiman agar tidak terjadi penurunan kualitas permukiman yang telah ada akibat pendirian bangunan baru maupun akibat kurangnya pemeliharaan terhadap fasilitas-fasilitas permukiman. Untuk melakukan langkah-langkah itu diperlukan sejumlah peta-peta tematik aktual kota. Hanya saja untuk membuat peta-peta tersebut secara terestnial dipenlukan biaya, tenaga, dan waktu yang tidak sedikit karena kondisi kota yang ramai, bentuk dan luas penggunaan lahan yang vaniasinya kompleks, dan banyak daerah padat yang sulit untuk diukur. Untuk mengatasi kendala dan keterbatasan cara terrestrial dalam pembuatan peta-peta aktual, dapat dilakukan altematif teknik Penginderaan Jauh sistem fotografik, dengan pendekatan multitemporal, foto skala besar. Pemanfaatan foto udara tersebut memungkinkan tersajinya data fisik kota secara detail dan dua atau lebih tahun pemotretan. Variabel fisik permukiman yang cukup banyak dan berbagai versi dapat diadopsi setelah dilakukan seleksi. Variabel permukiman yang memungkinkan untuk disadap dan foto udara, diantaranya: kepadatan bangunan, keteraturan bangunan, ukuran bangunan, aksesibilitas, lebar jalan masuk/jalan lingkungan, persil-persil, fasilitas-fasilitas umum permukiman, dan tutupan vegetasi. Vaniabelvariabel tersebut diinterpretasi dan foto udara, untuk dijadikan peta-peta tematik. Kemudian untuk menilai dan menganalisis kualitas permukiman, peta-peta tematik tersebut diolah dengan perangkat lunak Sistem Informasi Geografis (SIG). Hasil analisis itu dapat digunakan sebagai bahan pertimbangan dalam membuat keputusan dan kebijakan tentang permukiman kota.

Kata kunci : Penginderaan Jauh, SIG, kualitas permukiman

*) Penulis adalab stafpengajar pada Jurusan Pend. Geografi FIS UNY. 